MARTYNA CZARNECKA

Wydział Nauk Pedagogicznych

Forum Pedagogiczne

$9(2019) 2$, cz. 2

Uniwersytet Kardynała Stefana Wyszyńskiego

Wpłynęło: 22.09.2019

Warszawa

ORCI ID: https://orcid.org/oooo-0o03-4804-1728

\title{
DOJRZAŁE MACIERZYŃSTWO A KSZTAETOWANIE WIĘZI EMOCJONALNEJ Z DZIECKIEM W OKRESIE PRENATALNYM
}

Streszczenie: Przedmiotem rozważań niniejszego opracowania jest dojrzałe macierzyństwo w aspekcie kształtowania się więzi emocjonalnej z dzieckiem w okresie prenatalnym. Więź emocjonalna pełni w życiu człowieka znaczącą rolę. Wpływa na rozwój jednostki, zwłaszcza na płaszczyźnie emocjonalnej, społecznej i osobowości. Jest systemem biologicznie uwarunkowanym i stanowi istotny element egzystencji człowieka. Kształtuje się już na etapie prenatalnym i determinuje zachowania względem dziecka.

Współcześnie kobiety decydują się na macierzyństwo znacznie później, niż miało to miejsce jeszcze kilka lat temu. Przyczyny tego stanu rzeczy są różnorodne. Wśród najważniejszych zalicza się chęć osiągnięcia stabilizacji życiowej we wszystkich obszarach funkcjonowania człowieka. Początkowo kobiety pragną uzyskać stabilizację zawodową, następnie partnerską. Doświadczanie macierzyństwa jest elementem uzupełniającym egzystencję kobiety. Nie zajmuje kluczowej roli w jej życiu, lecz jest również ważne. Autor w niniejszym opracowaniu przedstawi dane empiryczne ukazujące proces kształtowania się więzi emocjonalnej z dzieckiem w trakcie trwania ciąży u kobiet doświadczających późnego macierzyństwa. W części teoretycznej zdefiniuje kluczowe pojęcia, scharakteryzuje przyczyny późnego macierzyństwa oraz proces kształtowania się więzi emocjonalnej w okresie prenatalnym.

Słowa kluczowe: dojrzałe macierzyństwo; więź emocjonalna; dziecko.

\section{Wprowadzenie}

Mimo istotnych przeobrażeń społeczno-kulturowych, gospodarczych i politycznych w przekonaniach wielu ludzi występuje stereotypowy sposób postrzegania macierzyństwa. Macierzyństwo bowiem kojarzone jest z młodymi kobietami, będącymi między 20 a 30 rokiem życia, a więc w tzw. optymalnym wieku rozrodczym. Zdaniem ginekologów jest to czas, kiedy młode kobiety lepiej znoszą ciążę, mają łatwiejszy poród, szybciej dochodzą do równowagi psychofizycznej po 
porodzie, a także istnieje mniejsze ryzyko urodzenia dziecka z wadami rozwojowymi. Podkreślają oni również aspekt lepszej relacji emocjonalnej, jaka kształtuje się między młodą matką a dzieckiem, ze względu na mniejszą różnicę wieku (Sawicka 2001).

W ostatnich latach w Polsce, jak również w innych krajach rozwiniętych, zauważa się jednak tendencje do coraz późniejszego wchodzenia w dorosłe role społeczne - role rodzicielskie. Z jednej strony jest to związane z polepszeniem warunków socjoekonomicznych, zmianami obyczajowymi i kulturowymi (Sawicka 2001). Z drugiej zaś - współczesne kobiety nastawione są na zdobycie wszechstronnego wykształcenia, znalezienie dobrze płatnej, satysfakcjonującej pracy zawodowej oraz ustabilizowanie swojej sytuacji na rynku pracy. Wszystkie te czynniki sprawiają, że wzrasta wskaźnik tzw. późnego macierzyństwa. Dane Głównego Urzędy Statystycznego, z lat 2013-2018, pokazują, że z roku na rok coraz więcej kobiet po 30 r.ż. decyduje się na urodzenie pierwszego dziecka. O około 70 proc. wzrosła również liczba kobiet, które urodziły dziecko pomiędzy 35 a 39 r.ż. Wzrosła także liczba kobiet, które decydowały się urodzić pierwsze dziecko po 45 r.ż., według raportów GUS o około 11 proc. (Raport GUS 2013-2018). Statystyki te jednoznacznie pokazują, że późne macierzyństwo to zjawisko powszechne i coraz częściej spotykane.

Podjęcie decyzji o posiadaniu potomstwa, a następnie narodziny dziecka dla większości kobiet to czas trudnych wyborów i doświadczeń, które pociągają zmiany na różnych płaszczyznach ich życia (Budrowska 200o). Zmuszają do reorganizacji i przewartościowania dotychczasowego sposobu życia. Wydawać by się mogło, że dojrzałe macierzyństwo powinno pociągać za sobą mniej trudności, przynajmniej na płaszczyźnie społeczno-emocjonalnej i osobowościowej. Kobieta świadoma swojego macierzyństwa, dojrzała społecznie i emocjonalnie, a na pewno w pełni samodzielna, powinna już w okresie ciąży nawiązać silną więź emocjonalną z dzieckiem. Jednak problemy na podłożu medycznym, które są w stanie zaburzyć właściwy przebieg ciąży, trudności z zajściem w ciążę, mogą spowodować, że doświadcza ona trudności emocjonalnych, co skutkować może zaburzeniami w kształtowaniu więzi emocjonalnej z dzieckiem w okresie prenatalnym (Lisowska 2013). W związku z powyższym nasuwają się pytania: czy późne macierzyństwo wiąże się z ukształtowaniem silnej więzi emocjonalnej z dzieckiem w trakcie trwania ciąży? Czy czas trwania ciąży powoduje zmianę więzi emocjonalnej z dzieckiem?

\section{Dojrzałe macierzyństwo w literaturze przedmiotu - ustalenia terminologiczne i przyczyny psychospołeczne}

W różnych kręgach kulturowych zrodziło się przekonanie, że macierzyństwo jest powołaniem kobiety. Jest istotną częścią natury kobiecej (Baranowska i in. 2017). Stanowi ważne zadanie rozwojowe oraz jest jedną z podstawowych ról społecznych i biologicznych. Społeczeństwo oczekuje od kobiet, niezależnie od jej możliwości, chęci i aspiracji, aby aktywnie uczestniczyła w reprodukcji gatunku. Społeczny 
„nakaz macierzyństwa” nierzadko stoi w opozycji do celów i pragnień wielu kobiet, które chcą pogodzić dwie sfery życia, własne aspiracje i obiektywne możliwości (Sikorska 1996). Dodatkowo przeobrażenia w strukturze rodziny, kryzys instytucji małżeństwa, niepewna sytuacja gospodarcza (niestabilność rynku pracy, duże bezrobocie) powodują, że kobiety odkładają na później decyzję o posiadaniu potomstwa.

Z jednej strony, słuszne wydawałoby się wydzielenie „jakiegoś” wieku, który rozgraniczyłby grupę młodszych i starszych kobiet w wieku rozrodczym. $Z$ drugiej zaś strony dojrzałe macierzyństwo mogłoby się odnosić do kobiet, które przekroczywszy pewną granicę wieku, zdecydowały się na urodzenie pierwszego dziecka (Sikorska 1996).

Z psychologicznego punktu widzenia, uznaje się, że okres właściwej dorosłości rozpoczyna się po 30 r.ż. Czas ten bowiem cechuje się względną stabilizacją, potrzebą dokonań, rozszerzaniem kręgów społecznych, pracą zawodową i pełnieniem różnych ról zawodowych oraz życiem rodzinnym i wzrostem odpowiedzialności jednostki. Osoba dorosła osiąga pełną dojrzałość społeczną, obywatelską odpowiedzialność, a także zdobywa i stara się utrzymać satysfakcjonującą działalność na płaszczyźnie zawodowej (Harwas-Napierała, Trempała 2014). Jest świadoma siebie, swoich potrzeb i możliwości. Zmniejsza się nastawienie egocentryczne na rzecz opieki, wsparcia i troski nad drugim człowiekiem. W związku z powyższym coraz mniej dziwi fakt, że kobiety po 3 o r.ż., które osiągnęły ową dojrzałość i stabilizację, decydują się na urodzenie dziecka.

Dojrzałe macierzyństwo dotyczy kobiet, które osiągnęły poczucie stabilizacji życiowej, zawodowej, uniezależniły się emocjonalnie i finansowo od pierwotnych obiektów przywiązania - rodziców oraz znalazły partnera życiowego. W literaturze ową dojrzałość kojarzy się także z posiadaniem tzw. „instynktu macierzyńskiego”. Oczywiście nie jest on zdeterminowany metryczką, jednak badania pokazują, że według kobiet dojrzałość ta osiągana jest najczęściej o około zo roku życia (ROPS, 2015). Połączona jest ona $z$ odpowiedzialnością, która przejawia się troską o drugiego człowieka i opieką nad nim. Wiąże się z psychologiczną potrzebą i gotowością do posiadania potomstwa.

Późne macierzyństwo należy analizować również na płaszczyźnie biologicznej, związanej ze wzrostem prawdopodobieństwa wystąpienia komplikacji w trakcie ciąży i porodu. Ginekolodzy informują o zagrożeniach związanych ze wzrostem częstości poronień, zgonów okołoporodowych, martwych urodzeń, większej umieralności w pierwszym roku życia dziecka (Szukalski 2012). „Niektórzy autorzy uznają, że już w wieku powyżej 25 lat pogarszają się rokowania w czasie ciąży i porodu, inni przyjmują za wiek graniczny 30, a nawet 40 r.ż." (Sawicka 2001, s. 246).

Biorąc pod uwagę powyższe rozważania, autor w niniejszej publikacji stosować będzie pojęcia późnego i dojrzałego macierzyństwa, dla określenia kobiet, które zdecydowały się na podjęcie się roli matki po 30 r.ż., które osiągnęły satysfakcjonującą pozycję społeczną, zawodową oraz niezależność finansową i stabilizację uczuciową. 


\section{Psychospołeczne przyczyny późnego macierzyństwa}

Satysfakcja kobiet z życia osobistego i zawodowego powoduje, że decyzja o posiadania potomstwa jest świadoma i przemyślana. Nie jest przypadkowa. Obecnie żyje się intensywnie i szybko. Kobiety decydują się na podjęcie roli matki po ukończeniu wymarzonych studiów oraz spełnianiu się na polu zawodowym, jak i uczuciowym. Pozwala to w konsekwencji oczekiwać na dziecko z większym spokojem i optymizmem (Kitzinger 1999). Psychospołecznych przyczyn dojrzałego macierzyństwa należy więc upatrywać w dwóch płaszczyznach: zawodowej i osobistej.

Biorąc pod uwagę aspekt zawodowy, do przyczyn późnego macierzyństwa zaliczyć należy z całą pewnością chęć zdobycia zadowalającej, dobrze płatnej pracy, podnoszenie swoich kwalifikacji zawodowych oraz osiągnięcie pozycji zawodowej, która gwarantuje kobiecie poczucie bezpieczeństwa. Owe poczucie bezpieczeństwa wiąże się zarówno z czynnikiem finansowym (stabilizacją materialną), jak również odnosi się do tzw. ciągłości zatrudnienia. Kobieta $\mathrm{z}$ większym stażem pracy i na wysokim stanowisku łatwiej może zaplanować ciążę i ma przy tym świadomość, że urodzenie dziecka nie spowoduje utraty dotychczas zdobytych, na gruncie zawodowym, korzyści.

Z całą pewnością dziecko daje matce poczucie zadowolenia, radości. Jednocześnie jest jednak źródłem zobowiązań, nierzadko niepokojów, zabiera energię i czas (Budrowska 2000). Idealny pracownik zaś jest człowiekiem bez rodzinnych zobowiązań, elastycznym, mobilnym, poświęcającym całą swoją energię na rozwój zawodowy. Posiadanie dziecka powoduje, że kobieta chcąca rozwijać się na płaszczyźnie zawodowej jest zmuszona pogodzić rolę matki, dbającej o obowiązki domowe i macierzyńskie, z rolą „idealnego pracownika”, gotowego poświęcić swój czas pracodawcy. W związku z tym wiele kobiet odkłada decyzję o posiadaniu dziecka na później. Jednak mimo tego, iż kultura polska nadal promuje określenie „matka-Polka”, co wiąże się z oczekiwaniami społeczeństwa wobec kobiet, że zrezygnują one ze swoich ambicji, pragnień, celów zawodowych na rzecz dziecka, męża i prawidłowego ogniska rodzinnego, to spotyka się liczne przypadki matek decydujących się na równoczesne podejmowanie tych różnorodnych ról społecznych (Sawicka 2001).

Również znajomość rynku pracy oraz świadomość sytuacji finansowej wpływają nierzadko na decyzję o pierwszej ciąży. Młode pracownice nie chcą stracić zdobytej pracy, zaś bezrobotne kobiety nie chcą narazić swojego dziecka na życie w ubóstwie.

Analizując przyczyny późnego macierzyństwa, ogromne znaczenie dla kobiet ma satysfakcja wynikająca ze związku partnerskiego. Biorąc pod uwagę statystki, współcześnie stale zwiększa się liczba rozwodów i par żyjących w nieformalnych związkach. Kobiety częściej niż wcześniej eksperymentują, zmieniają partnerów, żyją w wolnych związkach (Sawicka 2001). Osiągnięcie stabilizacji w życiu uczuciowym i partnerskim, polegające na wzajemnym zaufaniu i miłości, nierzadko rodzi się latami, dlatego też moment założenia rodziny stale się oddala. Łączy się to niezaprzeczalnie z permanentnym brakiem czasu oraz innymi życiowymi 
priorytetami kobiet, które utrudniają niewątpliwie pogodzenie różnorodnych ról społecznych.

Kolejnym istotnym czynnikiem, przekładającym się na odkładanie decyzji o posiadaniu potomstwa, jest brak gotowości emocjonalnej kobiet do podjęcia się roli matki. Chęć stworzenia szczęśliwej rodziny, o wysokim statusie socjoekonomicznym oraz pragnienie posiadania wysokich kwalifikacji i umiejętności umożliwiających prawidłowe wywiązywanie się z obowiązków opiekuńczo-wychowawczych powodują wystąpienie u kobiet tzw. ,stresu rodzinnego”. W związku z tym kobieta może mieć trudność $\mathrm{z}$ wyobrażeniem sobie siebie $\mathrm{w}$ roli matki, bądź owa wizja może być dla niej źródłem dużego napięcia, co w konsekwencji przekłada się na późne macierzyństwo.

Pomimo postępu cywilizacyjnego młodzi ludzie późno osiągają dojrzałość psychiczną i społeczną. Dłużej pozostają pod tzw. „opieką rodzicielską”. Zależność finansowa i emocjonalna od rodziców również uniemożliwia osiągnięcie samodzielności. Z kolei posiadanie potomstwa znacznie ogranicza swobodę i beztroskie życie. Oznacza przejście do „świata dorosłych”, w którym występują niekończące się obowiązki, odpowiedzialność za drugiego człowieka, często rezygnacja z własnych potrzeb, pragnień i planowanie życia pod kątem potrzeb innego człowieka (Budrowska 2000). Młody człowiek, mając perspektywę tak poważnych konsekwencji swoich działań, trudniej rezygnuje z egocentrycznego podejścia, pozostając dłuższy czas w świecie beztroski i niepełnej autonomii. Powoduje to, że świadoma decyzja o posiadaniu potomstwa przesuwa się na okres późniejszy.

Niedojrzałość kobiety do podjęcia się roli matki widoczna jest również w jej obawach i lękach przed ciążą, porodem i wychowaniem dzieci. Te rozterki psychiczne stanowią często mechanizm blokujący kobietę przed podjęciem decyzji o posiadaniu potomstwa.

Wskazane powyżej psychospołeczne oraz medyczne przyczyny późnego macierzyństwa niosą za sobą nie tylko konsekwencje w postaci odsuwania planów macierzyńskich na lata późniejsze, ale także mogą oddziaływać na proces kształtowania się więzi emocjonalnej w okresie prenatalnym, co niekorzystnie wpływa na dalszy rozwój dziecka.

\section{Więź emocjonalna jako strukturalny element życia człowieka}

W każdej jednostce istnieje biologicznie uwarunkowany system, który jest integralną częścią ludzkiej natury. Zapewnia on człowiekowi możliwość tworzenia silnych więzi emocjonalnych od najwcześniejszych etapów życia. Wpływa na zaspokojenie potrzeb człowieka, warunkuje jego nastawienie do świata. Pełni funkcję ochronną, która realizowana jest poprzez opiekę, troskę dojrzalszych jednostek wobec mniej dojrzałych, słabszych. Więź emocjonalna umożliwia przetrwanie organizmu. Jest potrzebą człowieka oraz fundamentalnym dynamizmem 
psychicznym. To specyficzny rodzaj relacji między podmiotami, ważny z punktu widzenia optymalnego rozwoju człowieka.

$\mathrm{W}$ literaturze jest wiele informacji na temat roli więzi emocjonalnej dziecka z rodzicem od momentu jego przyjścia na świat. Mało jest natomiast danych mówiących o jej znaczeniu w jeszcze wcześniejszym okresie, czyli w okresie prenatalnym. Już $\mathrm{w}$ trakcie ciąży przyszła matka nawiązuje z dzieckiem wyjątkową relację. Tylko poprzez kształtowanie się w tym okresie więzi emocjonalnej kobieta jest w stanie z pełną odpowiedzialnością troszczyć się o swoje jeszcze nienarodzone dziecko.

Twórca teorii przywiązania, John Bowlby, uważa, że więź, przywiązanie, jest trwałą, głęboką, emocjonalną więzią między dwiema osobami, które dążą do utrzymania bliskości fizycznej. Jest traktowana jako mechanizm biologiczny, niezbędny człowiekowi do przetrwania. Przywiązanie, jakie powstaje między podmiotami, jest kluczowym elementem planu rozwojowego, zapewnia zaspokojenie potrzeb oraz prawidłowy rozwój społeczno-emocjonalny i rozwój osobowości (Bowlby 2007). Więź potrzebuje nie tylko bliskości fizycznej, lecz także uczuciowej. Przyjmuje się, że ta druga odgrywa kluczową rolę w życiu człowieka, umożliwia aktualizację potencjału jednostki.

Już w okresie prenatalnym dziecko potrzebuje kontaktu z rodzicem. Poprzez opiekuńczo-wychowawcze oddziaływania rodziców, podejmowanie różnych prób komunikacji z nim, w dziecku rozwijają się: pierwotna wiedza o świecie (jaki jest świat, czy jest bezpieczny dla człowieka), nastawienie dziecka wobec świata, pierwsze emocje, kompetencje. Jeszcze przed urodzeniem kształtuje się w dziecku umiejętność nawiązywania relacji społecznych. Okres prenatalny to dla płodu pierwsza szkoła uczuć i społecznych interakcji (Kornas-Biela 2017). Dzięki prenatalnemu doświadczeniu miłości i bezpieczeństwa dziecko będzie w stanie czerpać radość z więzi ze światem społecznym po urodzeniu.

\section{Kształtowanie więzi emocjonalnej z dzieckiem w trakcie trwania ciąży u kobiet dojrzałych do macierzyństwa}

Od momentu poczęcia dziecka do wydania go na świat mija 40 tygodni. Do tej pory matka widzi swoje dziecko wyłącznie na ekranie monitora, podczas badania ultrasonograficznego. Nie może go dotknąć ani przytulić. Wydawać by się mogło, że sposoby sensorycznego kontaktu $\mathrm{z}$ dzieckiem $\mathrm{w}$ trakcie trwania ciąży są bardzo ograniczone. Jednak czas ten nie musi być pozbawiony intensywnego kontaktu. Dziecko czuje, słyszy, reaguje już na bardzo wczesnym etapie swojego rozwoju. Jest aktywnym odbiorcą wysyłanych w jego kierunku komunikatów. Badania pokazują, że doświadczenia $\mathrm{z}$ okresu prenatalnego mają istotne znaczenie w tym, jak człowiek później spostrzega świat, jak myśli, uczy się i reaguje emocjonalnie. Aby cechy indywidualne dziecka w okresie prenatalnym mogły się rozwijać prawidłowo ważna jest więź matki z dzieckiem. Kiedy matka zaczyna doświadczać pierwszych ruchów dziecka, koło 20 tygodnia ciąży, dostosowuje swoją aktywność 
do aktywności dziecka. Dba o siebie i dziecko, zaspokaja wzajemne potrzeby. Już w czasie ciąży pomiędzy matką a dzieckiem tworzy się wyjątkowa więź, która procentuje silnym emocjonalnym przywiązaniem w późniejszych etapach życia.

Więź można traktować jako pewien poziom zaangażowania rodzica w zachowania, które są wskaźnikiem jego przywiązania do nienarodzonego dziecka i wskazują na rodzaj interakcji z nim. Jest to tzw. model przywiązania prenatalnego, darzenia nienarodzonego dziecka bezwarunkową miłością, którą obserwuje otoczenie w przejawianych przez rodzica zachowaniach względem potomstwa (Bielawska-Batorowicz 2006).

Proces kształtowania się więzi emocjonalnej z dzieckiem nie jest procesem jednolitym. W literaturze można odnaleźć różne określenia tego procesu: postawa, przywiązanie, spostrzeganie dziecka przez rodziców, komunikowanie się z dzieckiem. Mówi to o „wieloaspektowości procesu tworzenia więzi i możliwości rozpatrywania do wielu punktów widzenia. Można wyróżnić [...] trzy jego najważniejsze elementy: traktowanie płodu jako odrębnej istoty, przypisywanie właściwości, podejmowanie prób kontaktu" (Bielawska-Batorowicz 2005, s. 12).

Traktowanie płodu jako odrębną istotę jest podstawą kształtowania się więzi $\mathrm{z}$ dzieckiem. Proces ten rozpoczyna się w momencie odczuwania ruchów płodu, które pojawiają się w drugim trymestrze ciąży. M. Leifer twierdzi podobnie, zwłaszcza w odniesieniu do ciąż planowanych. Badania J. M. Lumleya pokazują, że traktowanie płodu jako odrębną istotę wzrasta w miarę trwania ciąży. Stwierdza, po przeprowadzeniu rozmów z matkami spodziewającymi się pierwszego dziecka, że zaakceptowanie odrębności płodu jako istoty i docenienie własnych pozytywnych uczuć wobec dziecka, znacznie przyspiesza i ułatwia adaptację kobiecie do nowych warunków i roli zaraz po porodzie (Bielawska-Batorowicz 2005).

Czynnikiem utrudniającym kobiecie dostrzeżenie różnicy pomiędzy nią a dzieckiem, jak również kształtowania się więzi emocjonalnej względem niego jest poczucie nierealności istnienia. Zauważono, że kobieta początkowo koncentruje się na sobie, zaspokojeniu własnych potrzeb, nie wyobraża sobie dziecka, a tym bardziej nie przejawia w jego kierunku nadmiernych emocji, trudno jej np. okazać miłość do nienarodzonego dziecka. Dopiero rozpoznanie pierwszych ruchów dziecka powoduje, że ma ona świadomość jego realnego istnienia.

Przypisywanie dziecku właściwości definiowane jest poprzez opis jego cech wyglądu zewnętrznego, aktywności ruchowej oraz możliwości nawiązywania kontaktów z otoczeniem. Amerykańscy psychologowie wykazali, że najczęstszą kategorią określaną przez matki była aktywność ruchowa dziecka. Następnie skupiały się na określeniu jego nastroju, właściwości w kontaktach społecznych, wrażliwości i siły reakcji. Interesujący jest fakt, że płeć dziecka w okresie prenatalnym nie wpływa na przypisywanie dziecku określonych właściwości. Wpływ doświadczeń związanych z okresem ciąży niewątpliwie ma największe znaczenie w kształtowaniu się obrazu dziecka. 
Trzeci ze wskazanych elementów odnosi się do podejmowania prób kontaktu $\mathrm{z}$ nienarodzonym dzieckiem. Wymienić można różne formy tej komunikacji: „myślenie o dziecku, rozmowy z nim z użyciem specjalnych określeń, a nawet imienia, dotykanie powłok brzucha, śpiewanie piosenek i kołysanek, uspokajanie, pobudzanie do aktywności" (Bielawska-Batorowicz 2005).

Interakcja matki z dzieckiem pojawia się przez cały okres ciąży. Wykazuje się dużym zróżnicowaniem. Jej natężenie oraz formy kontaktu zmieniają się wraz $\mathrm{z}$ czasem trwania ciąży. Kontakt $\mathrm{z}$ dzieckiem w okresie prenatalnym jest istotny z punktu widzenia kształtowania się postaw rodzicielskich.

M. S. Cranley i Grace przeprowadziły badania nad zależnością pomiędzy wiekiem matki a procesem kształtowania się więzi emocjonalnej z dzieckiem. Wyniki ich badań nie ukazały zależności między badanymi zmiennymi. Inni badacze, jak np. Rees, byli zdania, że młodsze matki trudniej nawiązują więź z dzieckiem, zwłaszcza mają większy problem z traktowaniem dziecka jako odrębnej istoty o określonych, indywidualnych cechach. V. H. Kemp i C. Page z kolei stwierdzili, że mniejsze nasilenie więzi emocjonalnej z dzieckiem wykazują kobiety starsze, doświadczające późnego macierzyństwa. Podobne wyniki uzyskała również Eleonora Bielawska-Batorowicz (2005).

Kobiety decydujące się urodzić pierwsze dziecko po 30 r.ż. znacznie częściej, w porównaniu do młodszych kobiet, narażone są na komplikacje w trakcie ciąży, porodu i połogu. Przekłada się to także na więź emocjonalną z dzieckiem w okresie prenatalnym. Badania pokazują, że kobiety, które doświadczyły trudności z zajściem $\mathrm{w}$ ciążę, $\mathrm{w}$ porównaniu $\mathrm{z}$ tymi, które nie miały podobnych doświadczeń, bardziej koncentrują się na swoim nienarodzonym dziecku. Budują z nim silniejszą więź emocjonalną, skupiają się na dobrostanie dziecka w brzuchu, zastanawiają się nad jego zachowaniami i przeżyciami. Budują silniejsze wyobrażenie o dziecku (Pawlicka i in. 2013).

Badania nad problematyką więzi emocjonalnej z dzieckiem w okresie prenatalnym obejmują różne zagadnienia. Proces kształtowania się owego przywiązania należy rozpatrywać $\mathrm{w}$ dwóch aspektach. Po pierwsze, ważne jest zwrócenie uwagi na przeżywane przez matkę silne emocje względem dziecka. Po drugie, zaangażowanie $\mathrm{w}$ relacje $\mathrm{z}$ nim. Elementy te decydują o intensywności i jakości uczuć względem nienarodzonego potomstwa.

Niewątpliwie na rozwój więzi emocjonalnej z dzieckiem mają wpływ indywidualne właściwości rodziców, ich wzajemne relacje oraz sytuacja społeczna. Stałe konflikty między partnerami/małżonkami i kryzys w związku powodują, że kobieta nie czerpie satysfakcji z bycia matką, kształtuje negatywny obraz macierzyństwa, co niewątpliwie przekłada się również na proces rozwoju więzi emocjonalnej z dzieckiem. Kobiety, które walczą o swój związek, nie skupiają się na dziecku i kontakcie z nim. Działają bez przemyślenia, często pochopnie zaburzając proces kształtowania się więzi, ograniczając kontakt z dzieckiem do minimum. Wpływa to $\mathrm{z}$ całą pewnością na jakość relacji między matką a dzieckiem, nie tylko w okresie 
prenatalnym, lecz także w późniejszym okresie życia (Żelazkowska 2016). Również wszelkie powikłania w trakcie ciąży oraz wydarzenia życiowe, zwłaszcza te silnie stresujące kobietę, w sposób negatywny wpływają na siłę więzi emocjonalnej $\mathrm{z}$ dzieckiem.

Czynnikiem określającym jakość więzi emocjonalnej z dzieckiem jest także osobowość przyszłej matki. Badania pokazują, że kobiety, które w pozytywny sposób myślą o sobie oraz mają wysoką potrzebę współodczuwania, kształtują pozytywny obraz swojego macierzyństwa, co niewątpliwie współgra z jakością wytworzonej w okresie prenatalnym więzi emocjonalnej z dzieckiem. Wymienione cechy osobowości łączone są z pewną niezależnością wewnętrzną oraz wyższą dojrzałością emocjonalną, co może świadczyć o dojrzalszym przygotowaniu się do macierzyństwa.

Wyniki analiz procesu kształtowania się więzi emocjonalnej z dzieckiem w trakcie trwania ciąży pokazane przez różnych autorów wskazują na brak jednoznacznych danych na ten temat. Wyniki różnych badań z tego obszaru nie są ze sobą zgodne, prowadzą do sprzecznych wniosków. Przyczyn takiego stanu rzeczy należy upatrywać $\mathrm{z}$ jednej strony w odmiennym sposobie definiowania więzi, z drugiej zaś w zastosowanych w badaniach metodach i technikach badawczych.

\section{Metodologia badań własnych}

Celem niniejszego opracowania jest przedstawienie danych empirycznych ukazujących proces kształtowania się więzi emocjonalnej z dzieckiem w trakcie trwania ciąży u kobiet doświadczających późnego macierzyństwa. Ukazanie tego, czy wraz $\mathrm{z}$ czasem trwania ciąży zmienia się owa więź emocjonalna oraz w jakich obszarach zmiana ta jest zauważalna.

Postawiony cel pozwolił na sformułowanie następujących problemów badawczych: (1) Czy czas trwania ciąży powoduje zmianę więzi emocjonalnej z dzieckiem $\mathrm{w}$ trakcie trwania ciąży u kobiet doświadczających dojrzałego macierzyństwa? i (2) W jakich obszarach kształtowania się więzi emocjonalnej zauważa się zmianę $\mathrm{w}$ relacji z dzieckiem?

Dobór osób badanych był celowy. Kryteria, jakimi posłużono się w doborze respondentek, miały charakter typowo poznawczy. Były rezultatem wstępnego rozpoznania problemu badawczego. Przy doborze grupy starano się, aby aktualne miejsce zamieszkania kobiet było podobne, stąd wszystkie respondentki pochodziły z Olsztyna i jego okolic, a także z podobnego środowiska pierwotnego. Celem takiego doboru respondentek do grupy było wyeliminowanie czynnika zakłócającego, związanego m.in. z różnym dostępem do istotnych ośrodków rozwoju, np. uczelni wyższych czy też służby zdrowia i ośrodków kulturowych.

Podstawowym kryterium doboru kobiet do grupy było poczęcie pierwszego dziecka przez kobiety dojrzałe, które w trakcie badania były w przedziale wiekowym 30-35 lat. Łącznie przebadano 20 kobiet. 
Badania zostały przeprowadzone w prywatnych gabinetach ginekologicznych. W związku z głównym celem badania, oceną zmian więzi emocjonalnej z dzieckiem w trakcie trwania ciąży, badanie zaplanowano w trzech etapach. Pierwszy raz kwestionariusz kobiety wypełniały w pierwszym trymestrze ciąży, drugi raz $\mathrm{w}$ drugim trymestrze, a trzeci - $\mathrm{w}$ ostatnim, trzecim trymestrze ciąży.

W celu oceny więzi emocjonalnej z dzieckiem kobiet dojrzałych wykorzystano kwestionariusz Więźz dzieckiem wokresie ciąży, opracowany przez M. S. Cranleya. Adaptacji i tłumaczenia narzędzia badawczego na warunki polskie dokonała w 1995 roku Eleonora Bielawska-Batorowicz. Kwestionariusz pozwala ocenić różne aspekty więzi emocjonalnej w trakcie ciąży. Jest ona rozumiana jako natężenie zachowań przyszłej matki wobec nienarodzonego dziecka, polegających na nawiązywaniu z nim relacji i współdziałaniu z nim (Pawlicka 2013, s. 143). Kwestionariusz składa się z 24 twierdzeń. Osoba badana określa na skali pięciopunktowej: od zdecydowanie tak (5 pkt) do zdecydowanie nie (1 pkt) zgodność własnych opinii z treścią poszczególnych stwierdzeń. W kwestionariuszu zawarte są zdania odnoszące się do pięciu obszarów szeroko rozumianej relacji matka-dziecko:

- podejmowanie roli rodzicielskiej;

- traktowanie dziecka jako odrębnej istoty;

- nawiązywanie interakcji z dzieckiem;

- przypisywanie właściwości dziecku;

- podporządkowanie się interesom dziecka.

\section{Analiza wyników badań własnych}

Do analizy zmiany więzi emocjonalnej z dzieckiem w trakcie trwania ciąży przeprowadzono porównania pomiędzy średnimi uzyskanymi w trzech kolejnych pomiarach. W tym celu zastosowano jednoczynnikową analizę wariancji z powtarzanym pomiarem. W odniesieniu do jednej zmiennej traktowanie dziecka jako odrębnej istoty zastosowano nieparametryczny test rang F. Friedmana dla wielu pomiarów zależnych. Zmienna ta nie uzyskała rozkładu normalnego w drugim i trzecim trymestrze ciąży.

Wyniki badań ukazały, że więź emocjonalna $\mathrm{z}$ dzieckiem w trakcie trwania ciąży u kobiet dojrzałych jest coraz silniejsza, rozpatrując poszczególne trymestry ciąży (trymestr I $-M=86,60$, trymestr II $-M=97,65$, trymestr III $-M=102,65$ ). Potwierdza to wynik skali globalnej, który okazał się istotny statystycznie.

Dokonując analizy obszarów, w których zachodzi zmiana więzi emocjonalnej, badania pokazały, że kobiety dojrzałe zaczynają wraz z czasem trwania ciąży traktować dziecko jako odrębną istotę. W pozostałych wymiarach nie zaobserwowano różnic istotnych statystycznie.

Wyniki badań są zgodne z wynikami badań innych autorów. Wraz z czasem trwania ciąży więź emocjonalna jest coraz silniejsza. Może to wynikać z faktu, że 
Tabela 1. Porównanie rozwoju więzi emocjonalnej z dzieckiem w trakcie trwania ciąży u kobiet dojrzałych w kolejnych trymestrach ciąży

\begin{tabular}{|l|c|c|c|c|c|c|c|c|c|}
\hline \multirow{3}{*}{ Skala } & \multicolumn{7}{|c|}{ Trymestr ciąży } & \multicolumn{2}{|c|}{} \\
\cline { 2 - 11 } & \multicolumn{3}{|c|}{ I } & \multicolumn{2}{|c|}{ II } & \multicolumn{2}{|c|}{ III } & \multicolumn{2}{|c|}{} \\
\cline { 2 - 11 } & $M$ & $S D$ & $M$ & $S D$ & $M$ & $S D$ & $F$ & $d f$ & $p$ \\
\hline WG & 86,60 & 12,458 & 97,65 & 8,946 & 102,65 & 8,280 & 7,766 & 1,19 & 0,012 \\
\hline PRR & 15,65 & 3,498 & 17,70 & 1,922 & 18,80 & 1,735 & 2,660 & 1,19 & 0,119 \\
\hline NIzD & 15,10 & 3,919 & 18,65 & 2,777 & 19,50 & 4,628 & 2,786 & 1,19 & 0,111 \\
\hline PDW & 18,00 & 4,425 & 20,60 & 4,109 & 23,15 & 4,171 & 0,003 & 1,19 & 0,957 \\
\hline PsID & 21,60 & 2,683 & 21,85 & 2,581 & 21,85 & 2,412 & 0,331 & 1,19 & 0,572 \\
\hline TDJOI & 10,75 & 4,44 & 16,95 & 2,09 & 18,95 & 1,96 & 31,920 & 2,00 & 0,000 \\
\hline
\end{tabular}

Źródło: opracowanie własne; skróty: WG - wynik ogólny, PRR - Podejmowanie roli rodzicielskiej, NIzD - Nawiązywanie interakcji z dzieckiem, PDW - Przypisywanie dziecku właściwości, PsID - Podporządkowanie się interesom dziecka, TDJOI - Traktowanie dziecka jako odrębnej istoty.

w przypadku kobiet doświadczających późnego macierzyństwa ciąża jest świadoma i w pełni chciana. Kobieta jest dojrzała do podjęcia się roli matki.

Wyniki badań dotyczące zmian więzi emocjonalnej z dzieckiem w trakcie trwania ciąży w poszczególnych wymiarach okazały się w większości nieistotne statystycznie. Powodem tego stanu rzeczy może być niewielka grupa badawcza. Możliwe jest również pominięcie lub zbyt powierzchowne poruszenie wielu istotnych kwestii, co niewątpliwie spowodowane jest rozległością omawianego zagadnienia. W związku z tym niniejsze wyniki badań należy potraktować z pewną ostrożnością, dotyczą one bowiem wąskiego wycinka populacji. Niniejsze badanie można potraktować jako badanie pilotażowe. Może być ono podstawą do bardziej pogłębionego i złożonego badania naukowego.

\section{Zakończenie. Rekomendacje dla praktyki psychopedagogicznej}

Analiza literatury pokazała, że w wielu współczesnych dziedzinach wiedzy, takich jak: psychologia, pedagogika, medycyna, dużo uwagi poświęca się relacji matka-dziecko, kształtowanej od najwcześniejszych etapów, czyli już od okresu prenatalnego. Dziecko bowiem od samego początku swojego istnienia żyje „w matce i z matką". Jest od niej całkowicie zależne i to ona wpływa w dużej mierze na jego właściwy rozwój. Dojrzałość do roli macierzyńskiej warunkuje w kobiecie przystosowanie do ciąży i zachodzące w jej trakcie przemiany oraz akceptacja zmian w dotychczasowym życiu. Za najważniejsze bowiem zadania okresu ciąży, za R. Rubin, uznaje się: „zapewnienie kobiecie i dziecku bezpieczeństwa przez okres ciąży i porodu, uzyskanie akceptacji dla dziecka ze strony najważniejszych osób w rodzinie, nawiązanie więzi z mającym się urodzić dzieckiem oraz przystosowanie się do nowych zadań" (Włodarczyk 2012, s. 104). Ich realizacja pozwala przyszłym 
matkom doświadczać szczęśliwego i efektywnego macierzyństwa, jednocześnie pozytywnie wpływając na rozwój dziecka.

W licznych opracowaniach jest wiele informacji na temat ciąży, porodu, połogu i zagrożeń, a także biologicznych zalet i wad późnego macierzyństwa. Niewielką uwagę jednak przywiązuje się do okresu prenatalnego i znaczenia kształtowania się w tym czasie jednego z ważniejszych pierwiastków ludzkiej egzystencji, przywiązania, które ma wpływ na dalsze funkcjonowanie człowieka i rozwój jego osobowości. „Jakość macierzyństwa, którego doświadcza dziecko od pierwszych dni swojego życia, aż do dorosłości warunkuje w znacznej mierze to, jakim się staje ono człowiekiem" (Maciarz 2004, s. 7).

Stabilność przyszłych matek na płaszczyźnie zawodowej i rodzinnej powoduje, że kobieta przechodzi pozytywnie okres ciąży. Świadomość coraz sprawniej działającego systemu opieki zdrowotnej, lepsze diagnozowanie stanów patologicznych, które dają kobietom większą pewność, że mimo dojrzałego wieku dziecko może urodzić się zdrowe, przy jednoczesnym dobrym stanie zdrowia matki, sprawia, że coraz więcej kobiet decyduje się urodzić swojego pierwszego potomka w późnym wieku. Powyższe czynniki umożliwiają wytworzenie zaufania do osób sprawujących opiekę i troskę nad przyszłą mamą, co niewątpliwie oddziałuje na proces ciąży i wytworzenie właściwej więzi emocjonalnej z dzieckiem, bez poczucia zagrożenia.

Ciąża dojrzałych kobiet może wiązać się również z pewnym ryzykiem, niezwiązanym wyłącznie z aspektem medycznym, lecz z funkcjonowaniem psychologicznym przyszłych mam. Kobiety w różnorodnych okresach swojego macierzyństwa, również w okresie ciąży, mogą przeżywać z różnym nasileniem i częstotliwością znużenie, poczucie wyjałowienia, niedocenienia, izolacji (Milska-Wrzosińska 2005), modyfikacja bowiem ich dotychczasowego życia mogła być zbyt nagła lub silna. Znacznie rzadziej problem ten dotyczy młodszych mam, które urodziły pierwsze dziecko przed 30 r.ż., a więc w tzw. optymalnym wieku rozrodczym. Może to przełożyć się negatywnie na postrzeganie siebie, czyli na obraz siebie jako kobiety-matki oraz zdrowie psychiczne. To z kolei utrudnia proces kształtowania się właściwej relacji między matką a dzieckiem w okresie prenatalnym i późniejszym. $\mathrm{W}$ związku z powyższym należy zadbać o odpowiednią opiekę nad kobietami, które przeżywają cały wachlarz negatywnych stanów emocjonalnych od smutku, przygnębienia, poczucia braku sensu w życiu po złość i frustrację, a także dać im wsparcie. Tworzenie i zachęcanie kobiet doświadczających negatywnego, późnego macierzyństwa do czynnego udziału w grupach wsparcia pomoże im przepracować trudne emocje, zrozumieć sytuację i na nowo stworzyć właściwy obraz siebie $\mathrm{w}$ roli kobiety-matki.

Poczęcie dziecka i okres ciąży mogą być doświadczeniem wzbogacającym, stymulującym rozwój osobisty kobiety, niezależnie od jej wieku. Wytworzenie się więzi emocjonalnej między matką a dzieckiem już w okresie prenatalnym ułatwia odnalezienie się w roli matki po porodzie. Prowadzenie swoistego dialogu 
z dzieckiem w okresie ciąży daje natomiast poczucie świadomości istnienia dziecka i „włączenie go w całość biegu własnego życia” (Włodarczyk 2012, s. 123).

\section{Bibliografia}

Baranowska B., Bączek G., Doroszewska A., Tataj-Puzyna U. (2017). Doświadczenie macierzyństwa - badania sondażowe matek w Warszawie. „Fides et Ratio”, 2 (30), s. 124-144.

Bielawska-Batorowicz E. (2005). Determinanty spostrzegania dziecka przez rodziców w okresie poporodowym. Łódź: Wydawnictwo Uniwersytetu Łódzkiego.

Bielawska-Batorowicz E. (2006). Psychologiczne aspekty prokreacji. Katowice: Wydawnictwo Śląsk Katowice.

Bowlby J. (2007). Przywiązanie. Warszawa: Wydawnictwo PWN.

Budrowska B. (200o). Macierzyństwo jako punkt zwrotny w życiu kobiety. Wrocław: Wydawnictwo FUNNA.

Harwas-Napierała B., Trempała J. (2014). Psychologia rozwoju człowieka, t. 2, Wydawnictwo PWN, Warszawa.

Kitzinger S. (1999). Poród po 35 roku życia. Warszawa: Wydawnictwo Prószyński i S-ka.

Kornas-Biela D. (2017). Kształtowanie więzi rodziców $z$ dzieckiem w prenatalnym okresie życia. „Problematyka płodności i prokreacji”, 1 (29), s. 148-170.

Lisowska S. (2013). Ryzyko związane z ciąża po 35 roku życia. Pismo Małopolskiej Okręgowej Izby Pielęgniarek i Położnych. Kraków, s. 12-13.

Maciarz A. (2004). Macierzyństwo w kontekście zmian społecznych. Warszawa: Wydawnictwo Akademickie "Żak”.

Milska-Wrzosińska Z. (2005). Para z dzieckiem, czyli niezupełnie poprawne politycznie uwagi o rodzicielstwie. Warszawa: Jacek Santorski \& Co Agencja Wydawnicza.

Pawlicka P., Chrzan-Dętkoś M., Lutkiewicz K. (2013). Prężność psychiczna przyszłych matek oraz kolejność ciąży jako moderatory budowania więzi z nienarodzonym jeszcze dzieckiem. „Family Forum”, 3, s. 139-152.

Regionalny Ośrodek Polityki Społeczne Województwa Śląskiego. (2015). Społeczna rola matki - wyzwania współczesnego macierzyństwa. Raport z badania 2015. Projekt pt. „Kształcenie i doradztwo dla kadr pomocy i integracji społecznej województwa śląskiego", współfinansowany jest przez Unię Europejską w ramach Europejskiego Funduszu Społecznego.

Sawicka M. (2001). Socjomedyczne aspekty spóźnionego macierzyństwa, Rodzina w czasach szybkich przemian. „Rocznik Socjologii Rodziny”, XIII, s. 245-257.

Sikorska J. (1996). Kobiety i ich mężowie. Warszawa: Wydawnictwo IFiS.

Szukalski P. (2012). Późne macierzyństwo we współczesnej Polsce. „Demografia i Gerontologia Społeczna - Biuletyn Informacyjny", 6.

Włodarczyk E. (2012). O „rodzeniu się” macierzyństwa. W: Konteksty współczesnego macierzyństwa. Perspektywa młodych naukowców. Deręgowska J., Majorczyk M. 
(red.). Poznań: Wydawnictwo Naukowe Wyższej Szkoły Nauk Humanistycznych i Dziennikarstwa.

Żelazkowska M. (2016). Wczesne macierzyństwo - kryzys czy szansa. Olsztyn:

Olsztyńska Szkoła Wyższa im. J. Rusieckiego.

\title{
MATURE MOTHERHOOD AND SHAPING THE EMOTIONAL BOND WITH THE CHILD IN THE PRENATAL PERIOD
}

\begin{abstract}
The subject of the present study is mature motherhood in the aspect of shaping an emotional bond with the child in the prenatal period. Emotional bond plays a significant role in human life. It affects the development of the individual, especially on the emotional, social and personality levels. It is a biologically conditioned system and is an important element of human existence. It is already formed at the prenatal stage and determines the behavior towards the child.

Nowadays, women decide to become mothers much later than they did just a few years ago. There are various reasons for this. The most important is the desire to achieve life stability in all areas of human functioning. Initially, women want to achieve professional stability, before they establish a stable relationship with their partner. The experience of motherhood is an element complementing the existence of a woman. It doesn't occupy a key role in her life but is also important. In this article the author will present empirica data showing the process of shaping the emotional bond with the child during pregnancy in women experiencing late motherhood. In the theoretical part, I will define key concepts, characterize the causes of late motherhood and the process of emotional bond formation in the prenatal period.
\end{abstract}

Keywords: mature motherhood; emotional bond; child.

Martyna Czarnecka - doktor, adiunkt w Katedrze Psychologicznych Podstaw Pedagogiki na Wydziale Nauk Pedagogicznych UKSW. Jej główne przedmioty badań i zainteresowań naukowych to: psychologia kliniczna, zdrowia i terapia oraz psychoprofilaktyka społeczna. Adres korespondencyjny: Wydział Nauk Pedagogicznych UKSW, ul. Wóycickiego 1/3, budynek 15, o1-938 Warszawa. Adres e-mailowy: m.zelazkowska@wp.pl. 